\title{
Transgenic coffee fruits from Coffea arabica genetically modified by bombardment
}

\author{
Erika V. S. Albuquerque - Welcimar G. Cunha - Aulus E. A. D. Barbosa • \\ Poliene M. Costa • João B. Teixeira • Giovanni R. Vianna • Glaucia B. Cabral • \\ Diana Fernandez • Maria F. Grossi-de-Sa
}

Received: 28 July 2009 / Accepted: 3 September 2009 /Published online: 23 September 2009 / Editor: N. J. Taylor

(C) The Society for In Vitro Biology 2009

\begin{abstract}
The genetic modification of Coffea arabica fruits is an important tool for the investigation of physiological characteristics and functional validation of genes related to coffee bean quality traits. In this work, plants of $C$. arabica cultivar Catuaí Vermelho were successfully genetically modified by bombardment of embryogenic calli. Calli were obtained from $90 \%$ of the leaf explants cultivated in a callogenesis-inducing medium modified with $20 \mu \mathrm{M} 2$, 4-dichlorophenoxyacetic acid (2,4-D). The resulting calli were bombarded with the pBI426 vector containing a uidA and nptII gene fusion that was driven by the double CaMV35s promoter. Kanamycin-selected embryos were positive for $\beta$-glucuronidase (GUS) activity in histochemical assays and for target gene amplification by polymerase chain reaction. Integration of the nptII gene was confirmed by Southern blot and showed a low copy number (one to three) of insertions. Transformed plants showed normal development and settled fruits. GUS expression was assessed in the flower and fruit organs demonstrating the capacity of the double CaMV35s promoter to drive long-term stable expression of uidA in C. arabica fruit tissues. Moreover, we obtained a $\mathrm{T}_{1}$ progeny presenting 3:1 Mendelian segregation of the uidA
\end{abstract}

E. V. S. Albuquerque $(\bowtie) \cdot$ W. G. Cunha $\cdot$ A. E. A. D. Barbosa $\cdot$ P. M. Costa J. B. Teixeira - G. R. Vianna - G. B. Cabral •

M. F. Grossi-de-Sa

Embrapa Recursos Genéticos e Biotecnologia,

Laboratório de Interação Molecular Planta-Praga,

PqEB Av. W5-Norte (final),

Brasilia 707770-900 DF, Brazil

e-mail: erika.freire@ird.fr

\section{Fernandez}

Institut de Recherche pour le Développement,

Résistance des Plantes aux Bioagresseurs

IRD-UMR-186 IRD-Cirad-UM2,

BP 64501, 34394 Montpellier Cedex 5, France gene. This investigation is the first to report exogenous gene expression in coffee fruits and transgenic inheritance in C. arabica plants.

Keywords Coffea arabica - Genetic transformation . uidA gene - Coffee fruit expression · Bombardment

\section{Introduction}

Coffee, a beverage appreciated worldwide, yielded more than USD $\$ 13$ billion dollars in the international market in 2008 (ICO 2009). Approximately 130.7 million bags were produced in 2008-2009 generating millions of jobs in the tropical countries that produce coffee. Coffee species (Coffea spp.) are perennial woody shrubs. Coffea arabica, the most important commercialized species, is allotetraploid and autogamous, which makes it difficult to improve by conventional breeding (Etienne et al. 2002). The fruit of C. arabica requires 6 to 8 mo to mature covering the time between anthesis and full ripening.

Coffee biotechnology research has focused on isolating genes for improving fruit production, adaptability to the environment, and coffee-cup quality (Lin et al. 2005; Vieira et al. 2006). The importance of a better understanding of coffee fruit physiology was reviewed by De Castro and Marraccini (2006). They examined several important pathways involved in coffee berry development and metabolism, such as caffeine pathways, storage proteins ( $2 \mathrm{~S}$ and $11 \mathrm{~S}), \alpha$-Dgalactosidase, biosynthetic pathway of chlorogenic acids (e.g., PAL), sucrose metabolism (e.g., sucrose synthase), and ethylene production involved in the pericarp maturation (e.g., synthesis and catalyzation of ACC 1-aminocyclopropane-1carboxylic acid). Other workers have reported efforts toward genetically modified coffee plants with altered fruit traits. 
Aiming to increase uniformity of bean maturation, coffee cDNAs coding for ACC enzymes were cloned in order to modulate ethylene production in the fruits by expression of antisense sequences (Pereira et al. 2005). To produce coffee beans that are intrinsically deficient in caffeine, Ogita et al. (2004) produced C. canephora plants containing caffeine content reduced by up to $70 \%$ through the use of RNA interference (RNAi) technology aimed at the gene encoding theobromine synthase (CaMXMT1). Reduced levels of caffeine were demonstrated in the leaves of transgenic plants, but it was not shown whether caffeine content was also reduced in the beans.

The improvement of commercial fruit trees by genetic transformation presents many difficulties. There are only a few crops successfully transformed with genes of agricultural importance. One example is the Nicotiana alata proteinase inhibitor $(\mathrm{Na}-\mathrm{PI})$ that was introduced into apple (Malus domestica) plants to confer resistance to insects (Maheswaran et al. 2007). To control fruit ripening, ACC oxidase $(A C O)$ expression was modified in pear (Pyrus communis; Gao et al. 2007). However, in these works on perennial crop genetic modification, the transformed tissues analyzed are usually vegetative, i.e., leaves and shoots. One exception is the recent investigation by Torregrosa et al. (2008) in which transformed grapevine (Vitis vinifera L.) displayed altered levels of alcohol dehydrogenase $(A d h)$ in grape berry tissues.

The large number of expressed sequence tags (EST) sequences currently available (Fernandez et al. 2004; Lin et al. 2005; Vieira et al. 2006; Salmona et al. 2008) and other sequence information that will become available from genome projects will permit the study of many coffee genes that may potentially impart agronomic and consumer-preferred traits. It will be of particular interest to investigate seed physiology for the elaboration of final characteristics of coffee beans to obtain better cup quality. However, the identification and characterization of genes activated or repressed during coffee fruit development requires validation in vivo.

The uidA reporter gene, coding for the $\beta$-glucuronidase (GUS), has been proven to be a useful marker for following gene transfer to coffee plants. Different coffee cells and tissues were evaluated by GUS activity in the optimization of direct transformation methods (Van Boxtel et al. 1995; Fernandez-Da Silva and Menéndez-Yuffá 2003; Rosillo et al. 2003). The first transformed coffee plants obtained expressed the uidA gene (Spiral et al. 1993; Hatanaka et al. 1999). The C. canephora and C. arabica plants transformed with the cry1Ac gene from Bacillus thuringiensis to confer resistance to the leaf miner (Perileucoptera coffeella), also contained the uidA gene (Leroy et al. 2000). Ribas et al. (2005) transformed C. canephora by particle bombardment with genes conferring both resistance to phosphinotricin and GUS activity.
In this paper, we report the recovery of transgenic C. arabica that highly expressed the uidA gene in the ovaries, anthers, and endosperm of their fruits. Our results indicated that the uidA gene is correctly expressed by the control of the dCaMV35s promoter in the flower and fruit tissues of $C$. arabica. We also describe a direct transformation methodology that has potential to produce sufficient numbers of low copy transformants for both the improvement of $C$. arabica varieties and the functional validation of candidate genes.

\section{Materials and Methods}

Induction of embryogenic calli. The second pair of leaves from plagiotropic branches of $C$. arabica cv. Catuaí Vermelho was collected from plants that were grown in a greenhouse. These leaves were then surface-disinfected by a $3 \mathrm{~min}$ soak in $70 \%$ ethanol, followed by a soak in $2 \%$ sodium hypochlorite for $20 \mathrm{~min}$ and a rinse with distilled water repeated three times. Leaves were segmented $(0.5 \times$ $0.5-\mathrm{cm}$ pieces) and cultivated in petri dishes for $6 \mathrm{mo}$ in the dark at $25 \pm 2{ }^{\circ} \mathrm{C}$ on high frequency embryogenic induction medium, here called $\mathrm{C} 20$, based on medium $\mathrm{C}$ as described by Van Boxtel and Berthouly (1996) and modified by Teixeira et al. (2004). C20 consisted of half-strength Murashige and Skoog (Murashige and Skoog 1962) salts, $20 \mathrm{mg} / 1$ sucrose, $100 \mathrm{mg} / 1$ casein hydrolysate, $400 \mathrm{mg} / 1$ malt extract, $10 \mathrm{mg} / 1$ thiamine, $1 \mathrm{mg} / 1$ nicotinic acid, $1 \mathrm{mg} / 1$ pyridoxine, $1 \mathrm{mg} / 1$ glycine, $100 \mathrm{mg} / 1$ myoinositol, $20 \mu \mathrm{M}$ 2,4-D, $4.9 \mu \mathrm{M}$ indole-3-butyric acid, and $9.8 \mu \mathrm{M} 2$ isopentenyladenine, solidified with $2.4 \mathrm{~g} / \mathrm{l}$ Phytagel (Sigma Chemical Co.; St. Louis, MO). The pH was adjusted to 5.6 before autoclaving. During the incubation period in C20, explants were subcultured onto fresh medium only after the first month and then left in the same plates until the sixth month of culture.

Transformation procedure. After 6 mo of calli induction, yellow friable masses that had formed around the leaf explants were transferred to bombardment plates. Each bombardment plate was composed of a membrane containing approximately $50 \mathrm{mg}$ of embryogenic callus. Embryogenic mass was spread on a nitrocellulose membrane (BA85 with $0.45 \mu \mathrm{m}$ pore size; Schleicher and Schuell; Dassel, Germany) that was placed over modified $\mathrm{C} 20$ medium containing $10 \mu \mathrm{M}$ 2,4-D (C10) and incubated at $25 \pm 2^{\circ} \mathrm{C}$ in the dark for $6 \mathrm{~d}$ prior to microparticle bombardment. Membranes were then transferred to osmotic-conditioning medium ( $\mathrm{C} 10$ containing $0.5 \mathrm{M}$ mannitol and $8 \mathrm{~g} / 1$ Phytagel) and incubated at $25 \pm 2{ }^{\circ} \mathrm{C}$ in the dark for $24 \mathrm{~h}$ before bombardment.

The transformation experiment was composed of 12 bombarded plates. The vector used for bombardment was 
pBI 426 (Datla et al. 1991), which contains the $n p t I I$ gene conferring resistance to kanamycin and the uidA gene coding for the enzyme $\beta$-glucuronidase, which is driven by the double CaMV35s (dCaMV35s) promoter with an enhancer. Microprojectile sterilization and DNA precipitation were conducted according to Aragão et al. (1996). In a horizontal flux chamber, DNA was surface-deposited over $1.2 \mu \mathrm{m}$ tungsten microparticles (M10, Sylvania Inc.; New York, NY) previously prepared in suspension $(60 \mathrm{mg} / \mathrm{l}$ in $50 \%$ glycerol). For each shot, a $50-\mu l$ aliquot of microparticles was mixed with $5 \mu \mathrm{l}$ of vector $(1 \mu \mathrm{g} / \mathrm{ml}), 50 \mu \mathrm{l}$ of $2.5 \mathrm{M} \mathrm{CaCl}_{2}$, and $20 \mu \mathrm{l}$ of $100 \mathrm{mM}$ spermidine (Sigma), in this order. The mixture was gently inverted during $10 \mathrm{~min}$ and then centrifuged at $15,000 \times g$ for $10 \mathrm{~s}$. The supernatant was gently removed by pipetting, and the pellet was washed twice with absolute ethanol. Covered microparticles were finally suspended in $24 \mu \mathrm{l}$ absolute ethanol and passed three times $(1 \mathrm{~s}$ each time) in a sonication bath. Aliquots $(3.2 \mu \mathrm{l})$ were pipeted over carrier membranes (Kapton, 2-mil; DuPont, Belle, WV) and placed in a high-pressure heliumdriven particle acceleration device adapted from the system described by Sanford et al. (1991). Briefly, the bombardment chamber was maintained at approximately $50 \%$ relative humidity and $27 \mathrm{in}$. of $\mathrm{Hg}$ vacuum when 1,200 psi of helium pressure was applied to the shock-wave generation membrane. Bombardment physical parameters (Aragão et al. 1996) were 8-mm distance between the shock membrane and the DNA carrier membrane, 13-mm flying distance of the carrier membrane to the stopping screen, and $80-\mathrm{mm}$ flying distance of the DNA-coated microparticles to the explants. The bombardment plates were covered with a metallic screen (0.85-mm overture) to avoid spreading of the embryogenic callus during the shot. Immediately following bombardment, the membranes carrying bombarded calli were transferred to C10 medium without selection pressure and maintained at $25 \pm 2^{\circ} \mathrm{C}$ in the dark for $2 \mathrm{wk}$. Afterwards, the calli were subcultured on $\mathrm{C} 10$ medium that contained increasing concentrations of the selective agent kanamycin as follows: first week with $200 \mathrm{mg} / \mathrm{l}$, second week with $300 \mathrm{mg} / \mathrm{l}$, and then monthly with $400 \mathrm{mg} / \mathrm{l}$ until the appearance of resistant calli or embryos. Selected calli were cultured physically apart from each other to maintain traceability of the different transformation events. Regenerated somatic embryos were cultivated until they reached the torpedo stage on $\mathrm{R}$ medium (Van Boxtel and Berthouly 1996) that contained $400 \mathrm{mg} /$ 1 kanamycin. Regenerated embryos were then cultivated in baby food jars without the selection agent on woody plant medium (WPM; Lloyd and McCown 1981) containing $3 \mathrm{~g} /$ 1 activated charcoal and $2 \mathrm{~g} / \mathrm{l}$ Phytagel at $25 \pm 2^{\circ} \mathrm{C}$ under lowlight conditions $\left(7.5 \mu \mathrm{mol} / \mathrm{m}^{2} / \mathrm{s}\right)$ with a photoperiod of $16 \mathrm{~h}$. Derived plantlets were potted in vermiculite and soil $(1: 1 \mathrm{v} / \mathrm{v})$ and covered with plastic to be acclimated in a greenhouse with $40 \%$ to $50 \%$ shade. Covers were gradually opened to be completely removed after $2 \mathrm{wk}$ of acclimatization and permit the direct irrigation of the pots.

In the second year of greenhouse growing, fruits were collected from the selected event, identified as T4, to perform GUS activity tests and in vitro germination of the transformed zygotic embryos aiming to further propagate the $\mathrm{T} 1$ progeny by tissue culture. Red cherry fruits were disinfected before aseptic extraction of the zygotic embryos. Embryo cotyledonary samples were GUS-stained while axes were cultivated in WPM until acclimatization.

Histological analysis. Embryogenic calli, kanamycinresistant somatic embryos, and plantlets were tested before acclimatization for the histochemical detection of GUS activity (Jefferson et al. 1987). Samples were incubated overnight in the staining buffer modified by Lacorte (1998) and were observed under a stereomicroscope. The same GUS staining assay was used to analyze cut samples of flowers and fruits by microscopy. Four stages of the development relative to the days after anthesis (DAA; De Castro and Marraccini 2006) were collected corresponding to: (1) pin heads (15 DAA); (2) green immature cherry (115 DAA); and (3) mature cherry (230-240 DAA). Fruit materials from transformed plants were stained, dehydrated in a crescent ethanol battery, and embedded in paraffin. Longitudinal serial, semithin sections were treated with xylol and observed using a Zeiss axiophoto microscope. Cotyledonary samples from zygotic embryos ( $T_{1}$ generation) of the $T 4$ event were analyzed in X-gluc buffer as described previously.

Molecular analysis. The uidA gene was amplified by polymerase chain reaction (PCR) using the primers described by Moore et al. (1992). Genomic DNA from leaves of kanamycin-resistant in vitro plantlets were extracted by the CTAB method (Doyle and Doyle 1987) and analyzed as follows: $20 \mathrm{ng}$ of template were mixed with the buffer containing $1.2 \mathrm{mM} \mathrm{MgCl} 2,0.128 \mathrm{mM}$ dNTP, $1.5 \mathrm{U}$ Taq polymerase (Qiagen; Hilden, Germany), and $0.2 \mathrm{mM}$ primers (forward: 5'-TTGGGCAGGCCAGCGTATCGT-3' and reverse: $5^{\prime}$-ATCACGCAGTTCAACGCTGAC-3'). This mix was submitted to thermocycling $\left(95^{\circ} \mathrm{C} / 5 \mathrm{~min} ; 36\right.$ cycles: $95^{\circ} \mathrm{C} / 1 \mathrm{~min}, 55^{\circ} \mathrm{C} / 1 \mathrm{~min}$, and $73^{\circ} \mathrm{C} / 1 \mathrm{~min} ; 73^{\circ} \mathrm{C} / 5 \mathrm{~min}$ ) and the amplification products were analyzed by electrophoresis on a $1 \%(v / v)$ agarose gel.

The nptII gene was detected by Southern blot analysis (Sambrook et al. 1989) from four different transformation events. Genomic DNA was extracted using the DNAeasy Plant Kit (Qiagen) following manufacturer's instructions. Ten-microgram DNA samples were digested with BglII, $\mathrm{S} c a \mathrm{I}$, or $\mathrm{S} s p \mathrm{I}$ restriction enzymes and subjected to electrophoresis on a $1 \%(v / v)$ agarose gel. The DNA fragments were transferred to a Hybond $\mathrm{N}^{+}$membrane (Amersham ${ }^{\mathrm{TM}}$ Biosciences; Freiburg, Germany) by capillary blotting. The 
DNA-containing membrane was exposed to ultraviolet radiation to permanently attach the transferred DNA to the membrane. The nptII probe was obtained by BglII linearization of the pBI426 vector (Fig. 1) and isolation of the corresponding $811 \mathrm{bp}$ fragment on 1\%(v/v) agarose gel. The purified probe fragment was oligolabeled (Ready-ToGo kit, AGE Healthcare Biosciences Ltd.; Freiburg, Germany) and then used for overnight hybridization with the membrane at $65^{\circ} \mathrm{C}$. After excess probe washing, the membrane was maintained for $2 \mathrm{~d}$ at $-80^{\circ} \mathrm{C}$ for visualization by autoradiography (Kodak X-ray film, Eastman Kodak Co., Rochester, NY).

\section{Results}

Calli bombardment and regeneration of transformed embryos. Intense cellular proliferation was observed at the leaf explant's edge leading to primary calli formation in all explants (data not shown). Friable yellow masses from secondary embryogenic calli were obtained from $90 \%$ of the $C$. arabica leaf explants after 6 mo cultivation (Fig. 1a). Two leaf explants rendered sufficient material $(50 \mathrm{mg}$ of friable calli) for one bombardment shot. To avoid antibiotic toxicity on freshly bombarded calli, a new selection protocol was used wherein kanamycin doses were slowly increased during $4 \mathrm{wk}$ before reaching the highest dose (400 mg/l). After 2 mo on the selective medium supplemented with $400 \mathrm{mg} / \mathrm{l}$ kanamycin, most of the bombarded calli showed necrosis. In the third month of selection, we observed the appearance of both yellow friable calli and differentiating globular (Fig. 1b) and torpedo embryos (Fig. 1c). After a total of 4 mo under selective pressure with monthly subculture, 65 potential transformation events were obtained, most of them callus, but we also obtained some torpedo embryos. During a regeneration period on $\mathrm{R}$ medium for 2 mo in the dark, we transferred the fully developed embryos as soon as they reached the cotyledonary stage to light conditions on WPM containing activated charcoal (Fig. 1d). After approximately 6 months of subcultivation in WPM, we regenerated 178 somatic embryos with well-developed, green-colored cotyledons. Two months later, development of rootlets and leaves was observed (Fig. 1e). A total of 30 putative transformed plantlets were acclimated in soil in the greenhouse (Fig. 1f).

Analysis of the GUS stable expression and integration of the uidA gene. GUS histochemical assays were performed on randomly selected bombarded materials growing on medium supplemented with $400 \mathrm{mg} / 1$ kanamycin. Regenerated somatic embryos (Fig. 2a, b) sampled from such kanamycin-resistant material showed blue-colored stained cells indicating the presence of $\beta$-glucuronidase activity. Blue staining was also observed in the root tips and leaves (Fig. $2 c, d$ ) of all the embryos germinated in WPM.

Eleven samples from 12 events (T1-T12) assayed by PCR amplified 420-bp fragments (expected size) of the uidA gene (Fig. 3). Southern blots on DNA from four events (T3, T4, T5, and T8) showed integration of the nptII gene at different loci. Hybridization profiles obtained with the nptII probe confirmed integration and an estimated two to three copies of the nptII gene for the events T3, T5, and T8 (Fig. 4, lines 5, 6, 7). One event (T4) showed single-copy integration as revealed by the hybridization patterns of the DNA digestion with BglII, ScaI, and SspI (Fig. 4, lines 2-4).

Analysis of the genetically modified fruits. Transformed C. arabica plants from different events showed normal development and life cycle comparable to the nontransformed controls growing in the same greenhouse conditions. Forty-two flowers and 12 fruits (immature pin heads and green cherries) that developed after flowering in the second year of four transformed coffee plants, which were cloned from the single-copy event T4, were pooled for transgene
Figure 1. Explants for transformation and regeneration of transformed somatic embryos: (a) yellow masses of embryogenic calli produced from C. arabica cv. Catuaí Vermelho leaf explants; (b) appearance of kanamycin-resistant calli from bombarded explants; (c) torpedo-stage embryos grown on the R medium; (d) cotyledonary stage, selected embryos cultivated in WPM; (e) rooted plantlets before acclimatizing in greenhouse; (f) transformed plants.
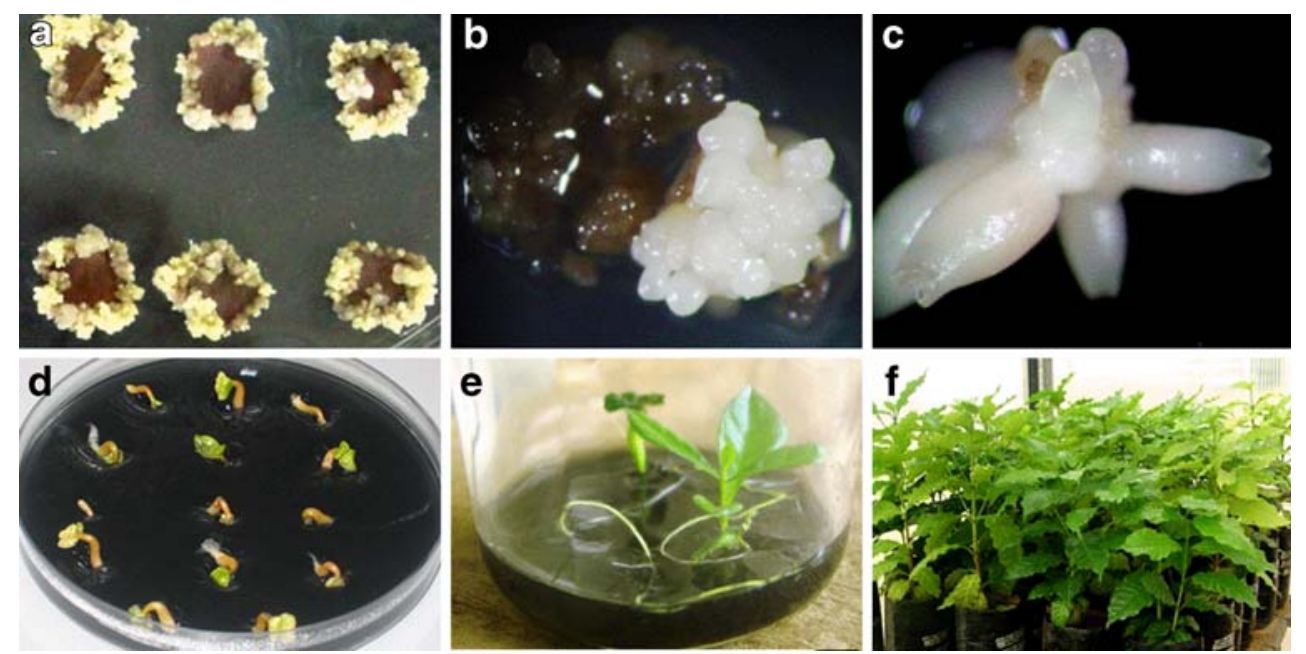
Figure 2. Stable GUS expression evidenced by histochemical analysis (blue coloration) of C. arabica kanamycin-resistant samples: (a) globular embryos; (b) cotyledon embryos;

(c) roots; and $(d)$ leaves.
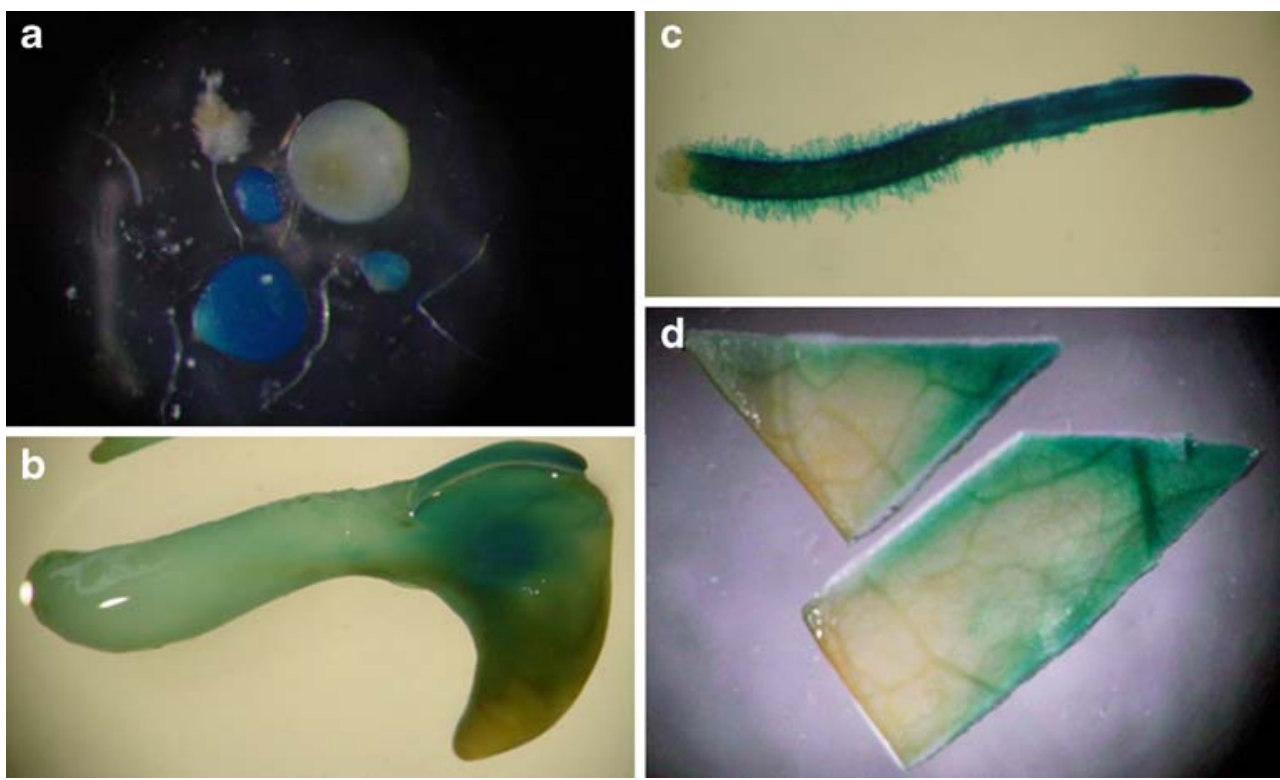

expression analysis. Flower buds showed various stained tissues including the floral verticil, receptacle, stigma, and anther (Fig. 5a) as well as pedicel and ovary (Fig. 5b). Histological cuttings showed that the ovary cells accumulated greater blue staining than the surrounding tissues (Fig. 5c). Similarly, coffee fruits collected 15, 115, and 230 DDA presented GUS staining mostly throughout the cut edge and the endosperm layers (Fig. 5d-f). Cotyledon samples from zygotic embryos ( $\mathrm{T}_{1}$ generation) of the $\mathrm{T} 4$ event plants $\left(\mathrm{T}_{0}\right.$ generation) showed blue staining (Fig. $5 g$ ) in $19(73 \%)$ samples out of the 26 total samples. This result corresponds to the segregation pattern of a single dominant gene $(3: 1)$ in a classical Mendelian fashion.

\section{Discussion}

The transformation procedures presented here show that the bombardment of embryogenic calli can be effectively used for introducing genes into $C$. arabica. We obtained an average of 5.4 putative transformation events per $50 \mathrm{mg}$ of bombarded explants from which at least one event/plate was positive for PCR amplification of the uidA gene. The osmotic treatment by mannitol performed before the bombardment could have favored the bombardment as reported for the transient expression in coffee cells (Rosillo et al. 2003). All samples from the 65 selected materials were GUS positive. Also, the progressive selection strategy, beginning with a 2 -wk interval without kanamycin after bombardment, seemed to positively influence the regeneration of the transformed $C$. arabica cells. About 178 embryos regenerated after more than 2 mo of selection in $400 \mathrm{mg} / 1 \mathrm{kanamycin}$. Since we observed a good transformation rate, it would be interesting to perform additional repetitions and new experiments to test variations in the selection strategy.

We analyzed 30 GUS-positive and kanamycin-resistant C. arabica plants from different transformation events after 2 years of maintenance in greenhouse. The nptII hybridization band patterns from the transformed $C$. arabica plants showed low-copy insertions, ranging from one to three copies. Transformed plants showed normal development and life cycle over this period comparable to the nontransformed control growing in the same conditions. Genetically-modified coffee fruits presented normal seed development, as reviewed by Eira et al. (2006), and generated zygotic embryos (T1) presenting Mendelian segregation pattern of the uidA gene expression.

We found that the dCaMV35s promoter drove high expression of the uidA gene in coffee beans. This marker system is still useful to determine the optimum conditions for gene transfer to fruit trees (Padilla et al. 2006; Maghuly et al. 2008) and to study gene expression in fruit tissues (Honda and Moriguchi 2006). It is important to notice that fruit-specific expression could be misinterpreted if indirectly assessed from different organs as observed by Torregrosa et al. (2008) in the responses of leaves and fruits of the

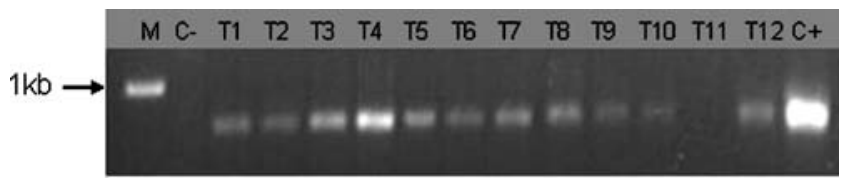

Figure 3. Detection of the uidA gene by PCR in 12 C. arabica transformants. PCR products were analyzed by electrophoresis on a $1 \%(v / v)$ agarose gel as follows: $(M)$ molecular marker, 1-kb DNA ladder; $(C-)$ negative control, DNA extracted from $C$. arabica cv. Mundo Novo; ( $T 1$ to $T 12$ ) DNA extracted from GUS-positive plants acclimatized in greenhouse; and $(C+)$ positive control, plasmid DNA from $\mathrm{pBI} 426$. 


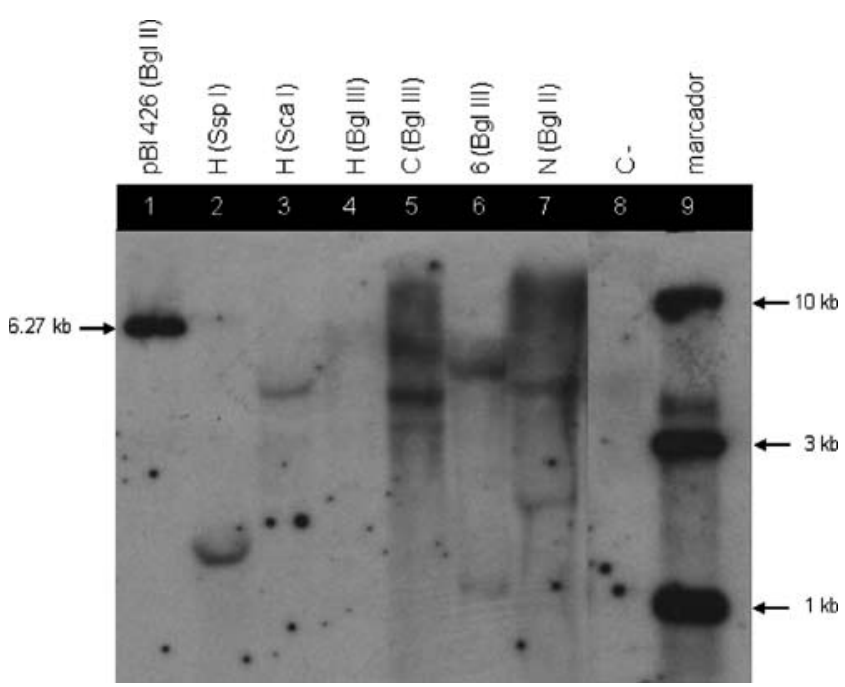

Figure 4. Southern blot analysis of $C$. arabica plants transformed with plasmid vector pBI426. DNA samples $(10 \mu \mathrm{g})$ from the T3 (5), T8 (6), and T5 (7) events were digested with BglII while DNA from the T4 event was digested with ScaI (2), SspI (3), and BglII (4). The $S s p$ I enzyme cuts at least twice into the vector producing a fragment near 1,524 bp. DNA-restricted fragments were hybridized with an oligolabeled nptII probe $(811 \mathrm{bp})$ obtained by digestion of pBI426 vector with SstI. The BglII-linearized vector $(350 \mathrm{pg})$ was used as positive control (1) while the BglII-digested DNA from a nontransformed $C$. arabica plant was the negative control (8). A high molecular mass ladder $(9)$ from Promega ${ }^{\circledR}$ was used throughout. same transformed grapevine individuals. Coffee fruits presented deepest blue staining in endosperm tissues in the present study (Fig. $5 d-f$ ) probably due to their metabolically high activity, which provides a source of carbohydrate and other reserves for the growing seedling (Dentan 1985; Bewley and Black 1994). Flower tissues were responsive to the GUS staining, but this material also presented some degree of oxidation, which partially hampered visualization of the GUS expression. Nevertheless, the presence of GUS in inner organs, such as the flower ovary, was confirmed in histological sections (Fig. $5 c$ ).

There is a demand for improving the genetic modification of $C$. arabica varieties because Arabica varieties are the most important genotypes for the global coffee market. While the genetic transformation of $C$. arabica tissues has already been achieved (Van Boxtel et al. 1995; Fernandez-Da Silva and Menéndez-Yuffá 2003; Rosillo et al. 2003), only a few regenerated and genetically modified plants were reported (Leroy et al. 2000), and no data is available about their offspring. The viability of the bombardment method to transform coffee was demonstrated previously in C. canephora (Ribas et al. 2005). Here, we describe the genetic modification by bombardment of $C$. arabica fruits that is similar to precursor work for transformation experiments with the $\alpha$-amylase inhibitor (Valencia et al. 2000), aiming to develop resistance of coffee plants to the coffee berry borer parasite (unpublished data). This methodology may be transferred
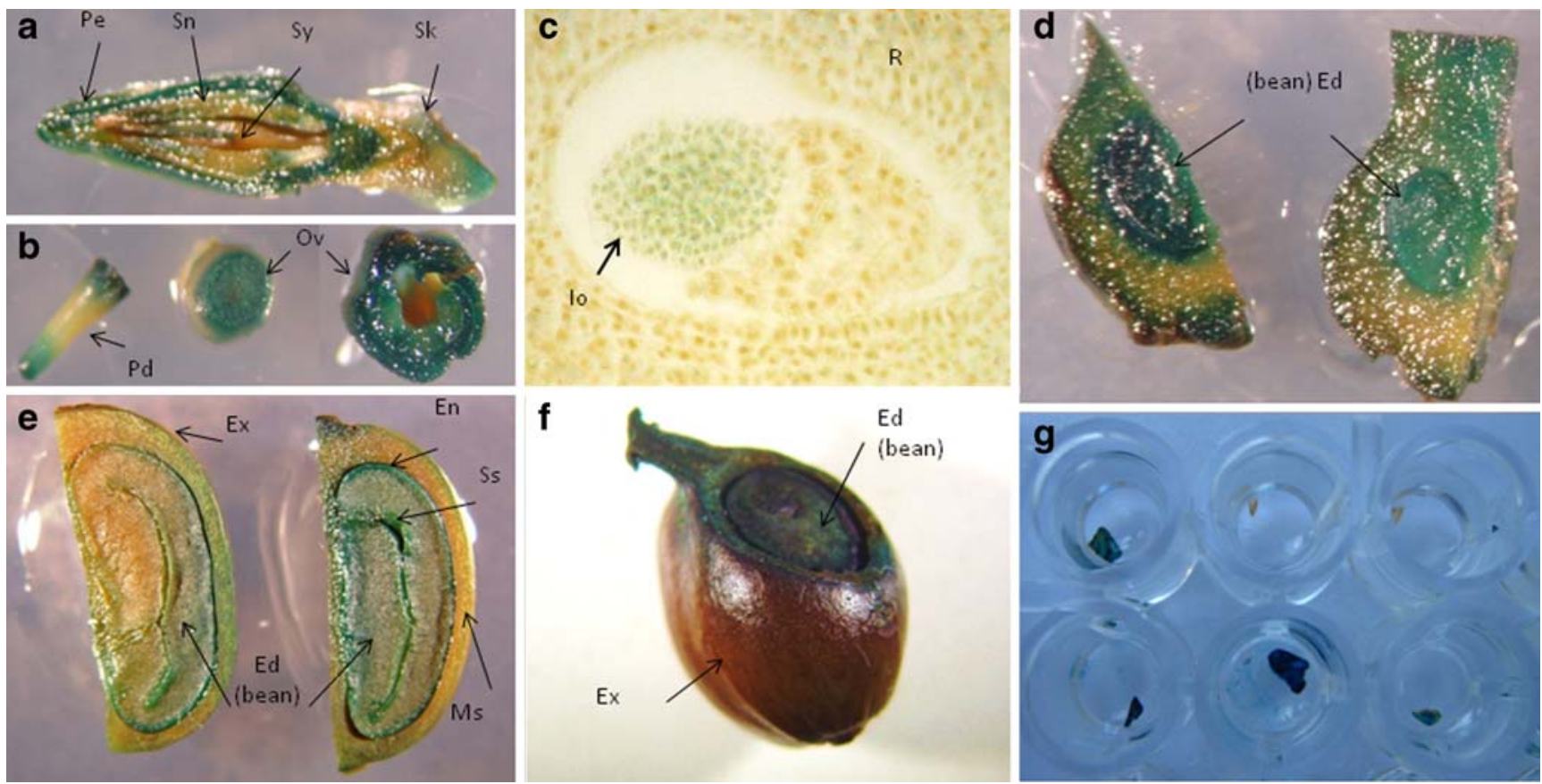

Figure 5. Cut samples from transformed $C$. arabica plants after GUS staining assays: ( $a$ ) flower bud divided in two; $(b)$ pedicel and initial seed development from ovary at the pin head stage; $(c)$ chopped pin heads; $(d)$ sliced bean of green immature cherry; $(e)$ whole mature cherry; $(f)$ ovary section under light microscopy $(\times 200)$, pin head longitudinal serial semithin sections stained with xylol; and $(g)$ cotyledon samples from zygotic embryos ( $\mathrm{T}_{1}$ generation) from the transformation event T4. Ed endosperm, Ex exocarp, En endocarp, $M s$ mesocarp, $S s$ silver skin, $O v$ ovary, $S k$ stalk, $S y$ style, $S n$ stamen, $P e$ petals, $P d$ pedicel, Io immature ovule, $R$ receptacle. 
from $C$. arabica Catuaí Vermelho to other coffee varieties considering that bombardment is not genotype-dependent as is Agrobacterium-mediated transformation. To our knowledge, the results presented in this paper constitute the first report of long-term, stable GUS expression and heritability of such a transgene in coffee fruits. While an initial report, the protocol described here constitutes a useful tool for the introduction of agronomic traits and for the functional validation of candidate genes in $C$. arabica fruits.

Acknowledgments $C$. arabica seeds were kindly provided by Dr. Antonio A. Pereira from EPAMIG. This research was supported by the "Consórcio Brasileiro de Pesquisa e Desenvolvimento do Café" and Embrapa.

\section{References}

Aragão F. J. L.; Barros L. M. G.; Brasileiro A. C. M.; Ribeiro S. G.; Smith F. D.; Sanford J. C.; Faria J. C.; Rech E. L. Inheritance of foreign genes in transgenic bean (Phaseolus vulgaris 1.) cotransformed via particle bombardment. Theor Appl Genet 93: 142-150; 1996.

Bewley J. D.; Black M. Seeds - physiology of development and germination. Plenum Press, New York; 1994.

Datla R. S. S.; Hammerlindl J. K.; Pelcher L. E.; Crosby W. L.; Selvaraj G. A bifunctional fusion between $\beta$-glucuronidase and neomycin phosphotransferase: a broad-spectrum marker enzyme for plants. Gene 101: 239-246; 1991

De Castro R. D.; Marraccini P. Cytology, biochemistry and molecular changes during coffee fruit development. Braz J Plant Physiol 18: 175-199; 2006.

Dentan E. The microscopic structure of coffee bean. In: Clifford M.; Wilson K. (eds) Coffee: botany, biochemistry and production of beans and beverage. Avi Publishing Company, Westport, pp 284 304; 1985

Doyle J. J.; Doyle J. L. A rapid DNA isolation procedure for small quantities of fresh leaf tissue. Phytochemical Bulletin 19: 11-15; 1987.

Eira M. T. S.; Amaral da Silva E. A.; de Castro R. D.; Dussert S.; Walters C. J.; Bewley D.; Hilhorst H. W. M. Coffee seed physiology. Braz J Plant Physiol 18: 149-163; 2006.

Etienne H.; Anthony F.; Dussert S.; Fernandez D.; Lashermes P.; Bertrand B. Biotechnological applications for the improvement of coffee (Coffea arabica L.). In Vitro Cell Dev Biol, Plant 38: 129-138; 2002.

Fernandez D.; Santos P.; Agostini C.; Bon M.-C.; Petitot A.-S.; Silva M. C.; Guerra-Guimarães L.; Ribeiro A.; Argout X.; Nicole M. Coffee (Coffea arabica L.) genes early expressed during infection by the rust fungus (Hemileia vastatrix). Mol Plant Pathol 5: 527-536; 2004

Fernandez-Da Silva R.; Menéndez-Yuffá A. Transient gene expression in secondary somatic embryos from coffee tissues electroporated with the genes gus and bar. Electron J Biotechnol 6: 29-38; 2003.

Gao M.; Matsuta N.; Murayama H.; Toyomasu T.; Mitsuhashi W.; Dandekar A. M.; Tao R.; Nishimura K. Gene expression and ethylene production in transgenic pear (Pyrus communis cv. "La France") with sense or antisense cDNA encoding ACC oxidase. Plant Sci 173: 32-42; 2007.

Hatanaka T.; Choi Y. E.; Kusano T.; Sano H. Transgenic plants of coffee Coffea canephora from embryogenic callus via Agrobacterium tumefasciens-mediated transformation. Plant Cell Rep 19: 106$110 ; 1999$.

Honda C.; Moriguchi T. High gus expression in protoplasts isolated from immature peach fruits. Sci Hortic 109: 244-247; 2006.

ICO International Coffee Organization. Global ICO site. http://www. ico.org/. Cited 20 Jun 2009; 2009.

Jefferson R. A.; Kavanagh T. A.; Bevan M. W. Gus fusions: $\beta$ glucuronidase as a sensitive and versatile gene fusion marker in higher plants. EMBO J 6: 3901-3907; 1987.

Lacorte C. B-glucuronidase (GUS). In: Brasileiro A. C. M.; Carneiro V. T. C. (eds) Manual de transformação genética de plantas. Embrapa/SPI, Brasília, pp 127-141; 1998.

Leroy T.; Henry A. M.; Royer M.; Altosaar I.; Frutos R.; Duris D.; Philippe R. Genetically modified coffee plants expressing the Bacillus thuringiensis cry1Ac gene for resistance to leaf miner. Plant Cell Rep 19: 382-389; 2000.

Lin C.; Mueller L.; McCarthy J.; Crouzillat D.; Pétiard V.; Tanksley S. Coffee and tomato share common gene repertoires as revealed by deep sequencing of seed and cherry transcripts. Theor Appl Genet 5: 1-17; 2005.

Lloyd G.; McCown B. Commercially-feasible micropropagation of mountain laurel, Kalmia latiforia, by use of shoot tip culture. Comb Proc Intl Plant Prop Soc 30: 421-427; 1981.

Maghuly F.; Khan M.; Fernandez E.; Druart P.; Watillon B.; Laimer M. Stress regulated expression of the gus-marker gene (uidA) under the control of plant calmodulin and viral $35 \mathrm{~S}$ promoters in a model fruit tree rootstock: Prunus incisa $\times$ serrula. $J$ Biotechnol 135: 105-116; 2008.

Maheswaran G.; Pridmore L.; Franz P.; Anderson M. A proteinase inhibitor from Nicotiana alata inhibits the normal development of light-brown apple moth, Epiphyas postvittana in transgenic apple plants. Plant Cell Rep 26: 773-782; 2007.

Moore G. A.; Jacono C. C.; Neidigh J. L.; Lawrence S. D.; Cline K. Agrobacterium mediated transformation of Citrus stem segments and regeneration of transgenic plants. Plant Cell Rep 11: 238 242; 1992.

Murashige T.; Skoog F. A revised medium for rapid growth and bioassays with tobacco tissue cultures. Physiol Plant 15: 473497; 1962.

Ogita S.; Uefuji H.; Morimoto M.; Sano H. Application of RNAi to confirm theobromine as the major intermediate for caffeine biosynthesis in coffee plants with potential for construction of decaffeinated varieties. Plant Mol Biol 54: 931-941; 2004.

Padilla I.; Golis A.; Gentile A.; Damiano C.; Scorza R. Evaluation of transformation in peach Prunus persica explants using green fluorescent protein (GFP) and beta-glucuronidase (GUS) reporter genes. Plant Cell Tissue Organ Cult 84: 309-314; 2006.

Pereira L. F. P.; Galvão R. M.; Kobayashi A. K.; Cação S. M. B.; Vieira L. G. E. Ethylene production and acc oxidase gene expression during fruit ripening of Coffea arabica 1. Braz J Plant Physiol 17: 283-289; 2005.

Ribas A. F.; Kobayashi A. K.; Pereira L. F. P.; Vieira L. G. E. Genetic transformation of Coffea canephora by particle bombardment. Biologia Plantarum 49: 493-497; 2005.

Rosillo A. G.; Acuna J. R.; Gaitan A. L.; de Pena M. Optimised DNA delivery into Coffea arabica suspension culture cells by particle bombardment. Plant Cell Tissue Organ Cult 74: 45-49; 2003.

Salmona J.; Dussert S.; Descroix F.; de Kochko A.; Bertrand B.; Joët T. Deciphering transcriptional networks that govern Coffea arabica seed development using combined cDNA array and real-time RTPCR approaches. Plant Mol Biol 66: 105-124; 2008.

Sambrook J.; Fritsch E. F.; Maniatis T. Molecular cloning: a laboratory manual. Cold Spring Harbor Laboratory, New York; 1989.

Sanford J. C.; Devit M. J.; Russell J. A.; Smith F. D.; Harpending P. R.; Roy M. K.; Johnston S. A. An improved, helium-driven biolistic device. Technique 3: 3-16; 1991. 
Spiral J.; Thierry C.; Paillard M.; Pétiard V. Regeneration of plantlets of Coffea canephora pierre (robusta) transformed by Agrobacterium rhizogenes. C R Acad Sci III, Sci Vie 316: 1-6; 1993.

Teixeira JB, Junqueira CS, Pereira AJPC, Mello RIS, Silva APD, Mundim DA. Multiplicação clonal de café (Coffea arabica L.) via embriogênese somática. Embrapa recursos Genéticos e Biotecnologia, Brasília; 2004: 39 pp.

Torregrosa L.; Pradal M.; Souquet J.-M.; Rambert M.; Gunata Z.; Tesniere C. Manipulation of $V v A d h$ to investigate its function in grape berry development. Plant Sci 174: 149-155; 2008.

Valencia A.; Bustillo A. E.; Ossa G. E.; Chispeels M. J. Amylases of the coffee berry borer (Hypothenemus hampei) and their inhibition by two plant amylase inhibitors. Insect Biochem Mol Biol 30: 207-213; 2000.

Van Boxtel J.; Berthouly M. High frequency somatic embryogenesis from coffee leaves. Plant Cell Tissue Organ Cult 44: 7-17; 1996.

Van Boxtel J.; Berthouly M.; Carasco C.; Dufour M.; Eskes A. Transient expression of beta-glucuronidase following biolistic delivery of foreign DNA into coffee tissues. Plant Cell Rep 14: 748-752; 1995.

Vieira L. G. E.; Andrade A. C.; Colombo C. A.; Moraes A. A. H.; Metha A.; Oliveira A. C.; Labate C. A.; Marino C. L.; MonteiroVitorello C. B.; et al. Brazilian coffee genome project: an ESTbased genomic resource. Braz J Plant Physiol 18: 95-108; 2006. 